\title{
Influence of radiographic osteochondrosis status at 16- 18 months, on racing performances in French trotters
}

\author{
Bertrand Langlois', Christine Blouin', Maëlle Perrocheau² and Stéphane Chaffaux² \\ Applied and Quantitative Genetics Station (Station de Génétique Quantitative et Appliquée)' and Cytogenetics and Biochemical Genetics Laboratory (Laboratoi- \\ re de Génétique Biochimique et de Cytogénétique)², CRJ, INRA, Jouy-en-Josas, France
}

\begin{abstract}
Summary
The aim of this study was to establish the relationship between the osteochondrosis status of 18-month-old colts and their racing and economic potential. Radiographic imaging was performed of the hocks and fetlocks of 740 yearling trotters at the time of sale. These radiographic diagnoses were then correlated to different criteria related to the racing career of the horse (qualification, number of starts, earning indices), and to its auction price. The study found that these ossification anomalies, detected just before training begins, have no influence on the performances and earnings of the trotters up to the age of four, or on their auction price. It is concluded that either these lesions have no negative effect on performance, or any negative effects are nullified by the medical-surgical environment of the animals.
\end{abstract}

Keywords: radiography, osteochondrosis, racing performance, sale price, trotter

\section{Röntgenologische Osteochondrosis-Befunde im Alter von 16 bis 18 Monaten in Bezug zur Rennleistung bei Französischen} Trabern

Die Osteochondrosis ist ein anerkannt schwieriges Problem in Pferdezucht und Pferdesport. Ziel dieser Studie ist es, beim Französischen Traber anhand von Röntgenaufnahmen einen Zusammenhang zwischen dem Auftreten der Osteochondrosis einerseits und den späteren Leistungen und dem wirtschaftlichen Wert der Tiere andererseits zu finden. Grundlage der Untersuchung sind Röntgenaufnahmen der hinteren Fessel- und Sprunggelenke von insgesamt 740 Französischen Trabern, die zwischen 1998 und 2002 geboren wurden. Die Informationen stammen aus einer einzigen spezialisierten Tierarztpraxis. Die Röntgenaufnahmen wurden bei den Pferden nach immer gleichem Ablauf durchgeführt, d.h. bevor die Tiere verkauft wurden bzw. ins Training kamen. Die Probanden waren zwischen 16 und 18 Monaten alt. An Fessel- und Sprunggelenken wurden röntgenologische Befunde im Sinne von Osteochondrose gesammelt und für jedes Gelenk und jede Seite jeweils mit einem Punkt bewertet. Die Addition der Punkte ergab die Gesamtbewertung. Diese Note wurde mit Klassenvariablen (Qualifikation, Traber Index-Klasse) und kontinuierlichen Variablen (Traber Index, Anzahl der Wettbewerbe im Alter von 2, 3, und 4 Jahre und Verkaufspreis) verglichen. Die Ergebnisse zeigen, dass keine der 55 durch geführte Analysen ein signifikantes Ergebnis gebracht hat. Es kann deshalb festgestellt werden, dass zumindest bis zu einem Alter von 4 Jahren kein sichtbarer Einfluss der röntgenologischen Befunde auf die spätere Leistung erkennbar war. Die erhobenen Befunde hatten entweder keine Auswirkung auf die Leistung oder die Tiere standen unter leistungsbeeinflussender Medikation. DieBefunde hatten auch keinen Einfluss auf den Auktionspreis.

Schlüsselwörter: Radiographie, Osteochondrosis, OCD, Rennleistung, Auktionpreis, Traber

\section{Introduction}

Osteochondrosis is a disorder of cartilage during growth. It is a syndrome of which the definition has been the subject of much debate (Pool 1993). The complex pathogenesis as described by Jeffcott and Henson (1998) gives rise to a wide variety of lesions and clinical signs. The origin of the syndrome is a failure of endochondral ossification that can affect any growth zone, leading to a thickening of the immature cartilage. It results in lowered mechanical resistance of the cartilage and the disturbance of its nutrition due to the inadequate supply of nutrients from the synovial fluid or the subchondral bone.

In the horse, lesions form progressively before one year of age (Jacquet et al. 2005). The first pathological form is the persistence of undifferentiated cartilage zones in the bone tissue. In some cases, the entrapped immature cartilage may become necrotic early on and transform itself into a mass that leads to the formation of a subchondral bone cyst. A crack may also occur in the necrotic cartilage that will reach the articular surface in most cases and will result in the partial detachment of a flap of cartilage. This phenomenon is referred to as an osteochondritis dissecans lesion. The fragment, ossified or not, can remain in place or detach completely, thus becoming a true "joint mouse" that will either move around in the joint, be reabsorbed or even attach itself to the articular capsule. In horses, the hock, fetlock and stifle are the joints where articular osteochondrosis is most common.

Radiographical detection of osteochondritis dissecans and cysts of the subchondral bone and the epiphysis make it possible to define the type and location of osteochondrosis lesions (Alvarado et al. 1989). The lesions of the stifle joint are most frequently associated with clinical signs (joint effusion, lame- 
ness) in young foals. For the other localisations, such signs may appear later on in life, but are relatively rare. Trauma may play a role in this late clinical manifestation and may give rise to lameness and (aseptic) arthritis (Jeffcott 1991).

Heritability plays a significant role in the occurrence of $O C$ in trotters (Willms et al. 1999, Ricard et al. 2002, Ricard 2004), in which it is frequently found. The prevalence of lesions is around $40 \%$ in this breed (Betsch and Desbrosse 2005), which is a concern in the sector since it may affect the entire musculoskeletal system and lead to a depreciation of the value of horses with the condition. Nevertheless, we must be particularly careful when addressing this issue, because many things are still unclear. Even the relationship between the lesions that can be detected on images and racing performance, as well as lameness, had not been clearly determined (Grøndahl et al. 1994, Grøndahl and Engeland 1995, Winter et al. 1996, Storgaard-Jørgensen et al. 1997, Brehm and Staecker 1999, Kane et al. 2003).

The aim of this study was to establish the relationship between the diagnosis of osteochondrosis lesions detected by radiographic imaging of the hock and fetlock of 16-18-month-old horses and their subsequent racing performances. At the same time, we analysed the impact of this radiological diagnosis on the economic value, determined by auction price.

\section{Methods and results}

Animals

Radiographic diagnoses were made of 740 French trotters born between 1998 and 2002. The four fetlocks and two hocks were systematically radio graphed and additional images of other joints of the hind legs, femoropatellar and femorotibial joints were also taken of some of the animals. These examinations were performed, either just before the yearlings were sold or just before training began. All horses were between 16 and 18 months old at the time.

\section{Radiological examinations}

The same methods as described Denoix et al. (1995) (taking at least six (four fetlocks and two hocks) bilateral radiographic images) were used for all horses. This examination was carried out under field conditions, by equine veterinary practitioners. Radiographs were interpreted by the same person, in this case the veterinarian responsible for the EQUITAS office in France, who is an officer specialised in examinations for equine insurances.

Radiographic images were scored as follows: for the fetlock joint, a score of 1 was given if at least one radiographic sign of osteochondrosis was observed in at least one of the fetlock joints. It concerned 169 horses out of 740. A score of 0 was given if no lesion was detected on these joints (571). The same scoring procedure was used for the hock joints, where fewer horses were affected (76). The overall score was the total of the radiographic images considered. It was 1 (227) if at least one image showed an osteochondrosis lesion and 0 (513) in the opposite case.
In order to take the severity of the lesions into consideration and to avoid any subjective judgement, we also scored the number of lesions uniquely as a function of the number of images of osteochondrosis observed. Therefore, the "lesion" score for the fetlock joint was 0 if no lesion was detected (571), 1 if one fetlock joint was affected (151), 2 if two fetlock joints were affected (18), 3 if three fetlock joints were affected, etc. In this sample, the lesion score for the fetlock joint never exceeded 2, these are three levels.

The lesion score for the hock joints was calculated in the same way, with three values: 0,1 and 2 concerning respectively 664, 74 and 2 horses.

The overall lesion score was the total of the two lesion scores for fetlock and hock joints. No horse could possibly obtain a score of 5 or 6 and none of them even obtained a 4 . This score therefore consisted of four possible values, including zero with the following numbers: 516, 191, 34 and 2 .

These scores only took into account radiographic images of osteochondrosis: osteochondritis dissecans and cysts of the subchondral bone and the epiphysis. In other words, all other juvenile osteo-articular lesions were excluded.

Moreover, a clinical diagnosis score for the lesions or a "severity" score (1, 2 or 3) was given by the veterinarian of the EQUITAS office, according to his prognosis. This last score was subjective and was based on the practitioner's experience. This concerned respectively 305, 336 and 99 horses.

\section{Performance evaluation and analysis models}

Ordinal variables such as qualification and $\mathrm{TI}$ (Trot Index) class were used, as well as continuous variables such as earning index (TI) and the number of starts.

The TI is a value that expresses the log of the average earnings per annual start, divided by the average earnings per start of horses in the same age, year and sex category, in a standardised value with an average of 100 and a standard deviation of 20 . The racing history of a horse is thus a succession of approximately standard normally distributed annual indices that make it possible to compare performances between years, age and sex (Langlois and Blouin 2004). This study only included performances at 2, 3 and 4 years of age.

\section{The $\mathrm{TI}$ classes were the following:}

1 no earnings, therefore no TI

$2 \mathrm{TI}<100$ small earnings

$3 \mathrm{TI}<120$ average earnings

$4 \mathrm{TI} \geq 120$ high earnings

In order to predict these performance variables, the logistics regression (Collet 2003, SAS 1999) was used in the case of ordinal variables and analysis of variance was used in the case of continuous variables (SAS, 1999).

The five adjusted models are summarised in Table 1. They take account of the fetlock joint score, the hock joint score, the overall score, the three corresponding lesion scores and 
Table 1 Summary of analysis results / Zusammenfassung der Ergebnisse

\begin{tabular}{|c|c|c|c|c|c|c|c|c|c|c|c|c|}
\hline \multicolumn{2}{|c|}{ Methods } & \multicolumn{4}{|c|}{ Logistics regression } & \multicolumn{7}{|c|}{ Analyses of variances } \\
\hline \multicolumn{2}{|c|}{ Dependent variables } & Qualification & \multicolumn{3}{|c|}{ TI class } & \multicolumn{3}{|c|}{ Starts } & \multicolumn{3}{|c|}{$\mathrm{TI}$} & \multirow{2}{*}{$\begin{array}{l}\text { Sale } \\
\text { price }\end{array}$} \\
\hline Age & & & 2 years & 3years & 4 years & 2 years & 3years & 4 years & 2 years & 3years & 4 years & \\
\hline \multicolumn{13}{|c|}{ Levels of variation factors } \\
\hline Fetlock score & $0-1$ & ns & ns & ns & ns & ns & ns & ns & ns & ns & ns & ns \\
\hline Hock score & $0-1$ & ns & ns & ns & ns & ns & ns & $s^{*}$ & ns & ns & ns & ns \\
\hline Overall score & $0-1$ & ns & ns & ns & ns & ns & ns & ns & ns & ns & ns & ns \\
\hline Fetlock lesions & $0-1-2$ & $\mathrm{~ns}$ & ns & ns & $\mathrm{ns}$ & ns & ns & ns & ns & $\mathrm{ns}$ & $\mathrm{ns}$ & ns \\
\hline Hock lesions & $0-1-2$ & ns & ns & ns & $\mathrm{ns}$ & ns & ns & ns & ns & $\mathrm{ns}$ & $\mathrm{ns}$ & ns \\
\hline Overall lesions & $\begin{array}{l}0-1-2- \\
3\end{array}$ & ns & ns & ns & ns & ns & ns & ns & ns & ns & ns & ns \\
\hline Severity score & $1-2-3$ & ns & ns & ns & ns & ns & $\mathrm{s}^{*}$ & ns & ns & ns & ns & ns \\
\hline \multicolumn{2}{|c|}{ Number of horses } & 568 & 740 & 568 & 354 & 43 & 280 & 177 & 36 & 239 & 147 & 372 \\
\hline
\end{tabular}

the clinical diagnosis ("severity") score given by the EQUITAS office in France.

By taking the simple score and the lesion score of the fetlokks and hocks, the overall score and the "severity" score into consideration, five analyses were successively carried out for each of the ten variables (qualifications, $\mathrm{Tl}$ classes at 2, 3 and 4 years of age, $\mathrm{Tl}$ at 2, 3 and 4 years of age and the number of starts at 2, 3 and 4 years of age), for a total of 50 analyses.

Moreover, the same models were applied to 372 horses with known auction prices, adding up to an additional five analyses. These prices were those of sales in Cabourg, Deauville and Vincennes (France). They are transformed into log values in order to normalise their distribution. When a horse is withdrawn from sale, it is not given a price. However, when it is sold again, it is attributed a resale price.

The results are summarised in Table 1.

\section{Discussion}

None of the 55 analyses carried out made it possible at the $5 \%$ level to determine a significant effect. Similar results had already been found in Scandinavia (Grondahl and Engeland 1995, Storgaard et al. 1997), in Germany (Brehm and Staecker 1999) and in the United States (Kane et al. 2003).

There are, however, two exceptions: The significant evolution of the number of starts at three years of age with values of 5.2, 6.0 and 7.3, when the "severity" score increases from 1 to 3. Horses with lesions on the hock joint are starting significantly more at four years of age than those without lesions: 11.1 times compared to 8.6. This last result appears to contradict observations made in the United States (Laws et al. 1993), who observed that horses treated for $\mathrm{OC}$ had significantly less starts (but equal earnings) compared to unaffected age-matched controls. .

Beard et al (1994) found that two-year-old Standardbreds operated for $\mathrm{OC}$ in the tarsocrural joint were less likely to race compared to unaffected 2 y-old siblings but not compared to unaffected $3 y$-old siblings. Brendov (1997) also found that lesions in hock joints without effusion did not affect athletic performance, but lesions in joints with effusion did. The study of Grondahl and Engeland (1995) also showed that trotters with tarsocrural $O C$ had a significantly lower number of starts and therefore somewhat lower earnings compared to controls. Given the results of the present study it can be questioned, however, if the clinical significance of $\mathrm{OC}$ is currently over estimated. In particular, the presence versus the absence of radiographic lesions of OC may not be of clinical significance. The matter is complex, however and in some cases nuance is indeed necessary, avoiding making things too simplistic.

This study differed from the preceding ones by the large number of animals taken into consideration and the time when radiographic images were taken, which was similar for all animals. The time chosen was between the period when the spontaneous recovery of lesions stops and the eventual appearance of anomalies due to trauma suffered during training. Moreover, the four fetlocks and the two hocks of all yearlings were radio graphically imaged under normal field conditions. The diagnoses of all of these examinations were read and scored by the same expert, taking only the lesions specific to osteochondrosis into account. It is nevertheless possible to criticize this study in that the radiological examination traditionally used to detect this disease is not always the best adapted since beginning lesions of the cartilage develop without any radiographically visible anomaly of the subchondral bone. The images do not identify, with certainty, all of the horses with osteochondrosis since many of the cartilaginous lesions, whether they are just beginning or already developed, are not visible on the images. However, those animals diagnosed as having the disease on the basis of this technique most certainly do. This is exactly what the practitioner is looking for in relation to the condition that is of interest to us here.

Some criticism could also be made according to some preselection of the horse material. Indeed, the costly radiographic examination was made only for horses that looked well 
and were not lame. This may reduce the potential variation in performance and consecutively reduce the observed correlation with the radiographic abnormalities. However, a significant number of horses were considered by the equine practitioner as severely affected (99/740) without leading to any significant effect on the achieved level of performance.

\section{Conclusion}

We conclude that up to the age of at least four years, the images of osteochondrosis detected by radiographic diagnosis made just before training began had no influence on the trotters' racing performances. This means that these lesions have either no impact on athletic ability or that ossification anomalies are totally under the control of the horses' medical-surgical environment. Moreover, the fact that these radio graphically-visible anomalies, known to potential buyers at the time of sale, have no influence on the auction price seems to be an argument in favour of this second hypothesis.

\section{Acknowledgements}

We would like to thank Jean-Marc Dufosset, doctor of Veterinary Medicine (Equitas France), for having made his radiographic results available to us, and Dr. Cécile Boyer for having provided us with the auction prices of the horses concerned.

\section{Literature}

Alvarado A., Marcoux M. and Breton L. (1989): Ostéochondrose chez le cheval: pathogénie, étiologie, signes cliniques et diagnostic radiologique. Le Point vétérinaire 21, 609-620

Beard W. L., Bramlage L. R., Schneider R. K. and Embertson R. M. (1994): Postoperative racing performance in Standarbreds and Thoroughbreds with osteochondrosis in tarsocrural joint: 109 cases (1984-1990). J. Am. Vet. Med. Ass. 204, 1655-1659

Betsch J. M. and Desbrosse F. (2005): L' ostéochondrose chez le poulain : particularité et attitude thérapeutique. Pratique vétérinaire équine 37, 87-92

Brehm W. and Staecker W. (1999): Osteochondrosis (OCD) in tarsocrural joint of Standardbred Trotters - Correlation between radiographic findings and racing performance. Proc. Am. Ass. Equine Practnrs. 45, 164-166

Brendov E. (1997): Osteochondrosis in Standardbred trotters-heritability and effects on racing performance. Thesis Swedish University of Agricultural Sciences, Uppsala, Sweden

Collet D. (2003): Modelling binary data. 2nd ed. Chapman and Hall. 387pp. Chapter3: Models for binary and binomial data

Denoix J. M., Houliez D., Moreau H., Audigié F., Robert C. and Blanchard L. (1995): Pathologie ostéo-articulaire juvénile chez le cheval - Etat actuel des recherches en France Compte-rendu de la 21 ième journée de la recherche équine, (Paris) 39-46

Grondahl A. M. and Engeland A. (1995): Influence of radiologically detectable orthopedic changes on racing performance in Standardbred Trotters. J. Am. Vet. Med. Assoc. 206, 1013-1017

Grondahl A. M., Gaustad G. and Engeland A. (1994): Progression and association with lameness and racing performance of radiographic changes in proximal sesamoid bone of young Standardbred Trotters. Equine Vet. J. 26, 152-155
Jacquet S., Robert C., Valette J.-P. and Denoix J.-M. (2005): Affections ostéo-articulaires juvéniles : dépistage et évolution des images radiologiques entre 6 et 18 mois. In: Compte-rendu de la 31 ème journée de la recherche équine, 2 mars 2005, Paris: Les Haras nationaux, 13-20

Jeffcott L. B. (1991): Osteochondrosis in the horse- searching for the key to pathogenesis. Equine Vet. J., 23, 331-338

Jeffcott L. B. and Henson F. M. D. (1998): Studies on growth cartilage in the Horse and their application to aetiopathogenesis of dyschondroplasia (Osteochondrosis). Vet. J. 156, 177-192

Kane A. J., Mcllwraith C. W., Park R. D., Rantanen N. W., Morehead J. P. and Bramlage L. R. (2003): Radiographic changes in Thoroughbred yearlings. Part2: Associations with racing performance. Equine Vet. J. 35, 366-374

Langlois B. and Blouin C. (2004): Practical efficiency of breeding value estimations based on annual earnings of horses for jumping, trotting, and galloping races in France. Livest. Prod. Sci. 87, 99107

Laws E. G., Richardson D. W., Ross M. W. and Moyer W. (1993): Racing performance of Standardbreds after conservative and surgical treatment of tarsocrural osteochondrosis. Equine Vet. J. 25, 199-202

Pool R. R. (1993): Difficulties in definition of equine Osteochondrosis; differentiation of developmental and acquired lesions. Equine vet. J., Suppl. 16, 5-12

Ricard A. (2004): Genetic backgrounds of osteochondrosis. In 55th Meeting of European Association for Animal Production, 24 September 2004, Bled, Slovenia. Communication n H2-2: 8pp.

Ricard A., Valette J. -P. and Denoix J.-M. (2002): Heritability of juvenile osteo-articular lesions of sport horses in France. In 7th World Congress on Genetics Applied to Livestock Production, 19-23 août 2002, Montpellier, France. Communication n ${ }^{\circ}$ 05-08

SAS (1999) SAS/STAT Software release 8.2 1999 PROC LOGISTIC and PROC GLM.

Storgaard-Jørgensen H., Proschowsky H., Falk-Rønne J., Willeberg P. and Hesselholt M. (1997): The significance of routine radiographic findings with respect to subsequent racing performance and longevity in Standardbred Trotters. Equine Vet. J. 29, 55-59

Willms F., Röhe R. and Kalm E. (1999): Genetische Analyse von Merkmalskomplexen in der Reitpferdezucht unter Berücksichtigung von Gliedmaßenveränderungen 1. Mitteilung: Züchterische Bedeutung von Gliedmaßenveränderungen. (Genetic analysis of different traits in horse breeding by considering radiographic findings - 1. Importance of radiographic findings in breeding sport horses.) Züchtungskunde, 71, 330-345

Winter D., Bruns E., Glodek P. and Hertsch B. (1996): Genetische Disposition von Gliedmaßenerkrankungen beim Reitpferd. (Genetic disposition of bone diseases in sport horses.) Züchtungskunde $68,92-108$

\section{Dr. Bertrand Langlois}

Applied and Quantitative Genetics Station

Station de Génétique Quantitative et Appliquée)

CRJ, INRA

78352 Jouy-en-Josas

bertrand.langlois@jouy.inra.fr 